\title{
Concrete Based on Clinker-Free Cement: Selecting the Functional Unit for Environmental Assessment
}

\author{
Olga Smirnova ${ }^{1, *(\mathbb{D})}$, Liliya Kazanskaya ${ }^{2}$, Jan Koplík ${ }^{3}\left(\mathbb{D}\right.$, Hongbo Tan ${ }^{4}\left(\mathbb{D}\right.$ and Xianyue Gu ${ }^{4}$ \\ 1 Department of Constructing Mining Enterprises and Underground Structures, \\ Saint-Petersburg Mining University, 199106 Saint-Petersburg, Russia \\ 2 Department of Building Materials and Technology, Emperor Alexander I St. Petersburg State Transport \\ University, 190031 Saint-Petersburg, Russia; yalifa@inbox.ru \\ 3 Materials Research Centre, Faculty of Chemistry, Brno University of Technology, CZ-61200 Brno, \\ Czech Republic; koplik@fch.vut.cz \\ 4 State Key Laboratory of Silicate Materials for Architectures, Wuhan University of Technology, \\ Wuhan 430070, China; thbwhut@whut.edu.cn (H.T.); 290589@whut.edu.cn (X.G.) \\ * Correspondence: smirnovaolgam@rambler.ru
}

Citation: Smirnova, O.; Kazanskaya, L.; Koplík, J.; Tan, H.; Gu, X. Concrete Based on Clinker-Free Cement: Selecting the Functional Unit for Environmental Assessment. Sustainability 2021, 13, 135. https://dx.doi.org/10.3390/su13010135

Received: 19 November 2020 Accepted: 15 December 2020 Published: 25 December 2020

Publisher's Note: MDPI stays neutral with regard to jurisdictional claims in published maps and institutional affiliations.

Copyright: () 2020 by the authors. Licensee MDPI, Basel, Switzerland. This article is an open access article distributed under the terms and conditions of the Creative Commons Attribution (CC BY) license (https: / / creativecommons.org/ licenses/by/4.0/).

\begin{abstract}
Improving the environmental situation and obtaining cement composites with new properties for various operating conditions is possible with the use of secondary resources. The paper is devoted to the criteria for evaluating the impact of clinker-free cement on the environment. The methodological approach to the selection of a functional unit for comparative assessment of the ecological footprint of clinker-free cements is justified. The results of studying the properties determining the concrete durability in the aggressive environment of livestock farms and in transport construction are given. The results will contribute to the development of an ecological approach to the components selection for clinker-free cements and to the adoption of design decisions in construction, as well as to the expansion of the field of using clinker-free cements in transport and industrial construction.
\end{abstract}

Keywords: carbon footprint; functional unit; durability; frost resistance; aggressive environment of livestock farms; concrete for railway sleepers

\section{Introduction}

Issues of environmental protection through the development of technologies, with low carbon dioxide emissions, using secondary resources, are becoming global [1-6]. The production of cements and building materials is an industry that can make a significant contribution to the integrated processing of secondary resources [7-12]. Cement composites account for the main share in the production of materials. The involvement of secondary resources in their production allows for improving the environmental situation, as well as for obtaining composites with new or improved properties [13-16].

Clinker-free cements are mainly represented by alkali-activated cements. Alkaliactivated binders consist of two components: inorganic powder and an alkaline activator of hardening $[17,18]$. Water solutions of calcinated soda, sodium sulfate, sodium hydroxide, liquid glass, and so forth, can be used as an alkaline activator [19-25].

At present, the study of clinker-free cements is aimed at the theoretical and practical justification of obtaining new compositions, based on multicomponent mineral raw materials of secondary resources for durable cement matrices, at the expense of increasing the reactivity of binders, reducing their water demand, directing regulation of the processes of phase and structure formation, and their correlation with the processes that determine the internal corrosion of the matrix [26-31]. This leads to increasing the physical and mechanical properties that determine the matrix durability [32-34]. However, high strength is not the only condition for ensuring matrix durability $[31,35]$; it is necessary to consider other properties that determine the material durability in the required operating conditions. 
There are instances of using alkali-activated slag concrete in difficult operating conditions, such as concrete for railway sleepers and floor structures of livestock farms [36-38]. This makes it possible to discuss the environmental impact of these cements below.

Assessment of the environmental impact of binders is an important criterion when developing compositions of these binders and selecting the components [39-42]. The technology of clinker-free cements should combine issues such as saving Portland cement clinker, recycling industrial wastes, and obtaining concrete with new and improved properties [43-47].

At present, there are not enough published data related to the quantitative assessment of the impact of clinker-free cements on the environment. This can be explained by several reasons. First, there is insufficient data confirming the successful use of these cements in complicated operating conditions and, accordingly, justifying their durability. Second, there is little information available about the specifics of producing new cements on an industrial scale, and it is also rarely subjected to independent impartial assessment of environmental indicators, mainly due to commercial restrictions. It should be noted that manufacturers of clinker-free cements face barriers such as regulatory restrictions, slow adaptation of standards, and unwillingness to use materials with less studied properties, despite the technical and environmental advantages of clinker-free cements compared to Ordinary Portland cement (OPC). Hence, the choice of construction material and technology should be justified not only on the basis of technical and economic comparison but also on their environmental impact.

Existing studies on the assessment of environmental impact of cement are based on the process-based life cycle assessment (LCA). The ISO14067 standard was developed for the quantitative assessment of the carbon footprint (CF) of products, and is based on greenhouse gas emissions normalized to the carbon dioxide equivalent $\left(\mathrm{eCO}_{2}\right)$ and on LCA methodology. The results of the quantitative determination of the $\mathrm{CF}$ are expressed in mass of $\mathrm{eCO}_{2}$ per functional unit.

Published results on the quantitative assessment of the CF of cement vary significantly $[48,49]$. The environmental advantage in these studies is given to various binders: clinker-free cements, low-clinker cements, and OPC. This leads to ambiguous conclusions regarding the $\mathrm{CF}$ from the use of supplemental cementitious materials in binders. As a rule, this is explained by the difference in production technology (for example, by the use of alternative fuels) or the need for transporting the components using transport with a high CF. These factors make significant changes to the CF of products.

According to ISO14067, the product CF is assessed in order to compare the environmental impact of a product on the climate and make strategic or design decisions. For comparability of the results obtained, the product evaluations should be carried out using identical methods. This, in turn, may call into question the published comparative results on estimating the $\mathrm{CF}$ of cements obtained from various sources.

Most studies that assess cement $\mathrm{CF}$ use a functional unit based on mass measurement units (kgs or tons). However, researchers show that taking other characteristics into account is an equally important approach. The authors [50,51] have shown that accounting for the cement compressive strength in a functional unit affects the results of the LCA study. Cements with less clinker will always show less environmental impact when using mass as a functional unit, although much lower values of strength or service life of the cement concrete could be obtained [52]. Therefore, there are some doubts concerning the actual environmental performance of cements since most LCA studies of cement production use a functional unit based on mass measurement units.

It is important to take into account the main properties of cement (i.e., compressive strength and concrete durability) in order to evaluate and compare its environmental characteristics. This will contribute to the development of clinker-free cements, paying more attention to the cement properties than its composition [53]. The need for revising the functional unit based on mass measurement units was indicated in the papers $[52,54]$ for a 
meaningful comparison of cements and concretes, taking into account certain properties such as compressive strength, service life, and thermal conductivity.

The authors of this paper hypothesize that the selection of a functional unit for a quantitative assessment of the carbon footprint of concrete should be performed, taking into account the concrete properties for the required operating conditions. It should be a comparative assessment using an identical methodology to justify the choice of the kind of cement (Portland cement, clinker-free cement, etc.) for a specific construction object. This choice should be based both on the feasibility study of the choice of cement and its environmental impact.

At present, the standards of designing in construction provide for the selection of cement and concrete for a certain object based on a feasibility study. However, the assessment of the comparative environmental impact of concrete should be provided in the regulatory documentation. With this environmental assessment, the projects in which concretes are used, on the basis of clinker-free cements, can benefit in many severe operating conditions.

\section{Materials and Methods}

The cements CEM III 22.5, CEM I 32.5, and CEM I 52.5 were used. Ground granulated blast furnace slags of metallurgical plants located in the Southern Ural were used (Table 1). These slags are slightly acidic according to a basicity modulus of $\mathrm{M}_{\mathrm{O}}=0.8-0.91$, with an increased amount of alumina of $14-16 \%$ and a crystallization degree of $5-8 \%$.

Table 1. Chemical composition of slag, \%.

\begin{tabular}{ccccccccc}
\hline Slags & $\mathrm{SiO}_{2}$ & \multirow{2}{*}{$\mathrm{A1}_{2} \mathrm{O}_{3}$} & $\mathrm{CaO}$ & $\mathrm{MgO}$ & $\mathrm{SO}_{3}$ & $\mathrm{FeO}$ & $\mathrm{Fe}_{2} \mathrm{O}_{3}$ & $\mathrm{MnO}^{n}$ \\
\hline Beloretsky slag (No.1) & 37.00 & 16.00 & 39.30 & 3.00 & 0.62 & 1.00 & - & $\mathrm{TiO}_{2}$ \\
Magnitogorsky (No.2) & 35.68 & 14.32 & 40.09 & 5.54 & 1.17 & - & 0.84 & 0.80 \\
\hline
\end{tabular}

A study of wastes in the chemical industry of the Southern Ural region showed the presence of a number of materials that can be used as lime- and sulfate-containing hardening activators for slag binders without significant technological processing (Tables 2 and 3). Phosphogypsum of Joint Stock Company JSC "Meleuzovskie mineral fertilizers", used in experiments as a sulfate-containing activator, has the following composition: $\mathrm{CaSO}_{4} \cdot 2 \mathrm{H}_{2} \mathrm{O}-94.6 \%$, $\mathrm{CaHPO}_{4}$-traces, $\mathrm{Ca}_{3} \mathrm{PO}_{4}-1.31 \%, \mathrm{H}_{3} \mathrm{PO}_{4}$ and $\mathrm{Ca}\left(\mathrm{H}_{3} \mathrm{PO}_{4}\right)_{2}-0.47 \%$.

Table 2. Chemical composition of lime-containing wastes of Joint Stock Company JSC "Bashkir soda company", \%.

\begin{tabular}{|c|c|c|c|c|c|c|c|c|c|}
\hline Waste & $\mathrm{SiO}_{2}$ & $\mathrm{CaO}$ & $\mathrm{MgO}$ & $\begin{array}{r}\mathrm{K}_{2} \mathrm{O} \\
+\mathrm{Na}_{2} \mathrm{O} \\
\end{array}$ & $\mathrm{A1}_{2} \mathrm{O}_{3}$ & $\mathrm{Fe}_{2} \mathrm{O}_{3}$ & $\mathrm{SO}_{3}$ & $\begin{array}{c}(\mathrm{CaO} \\
+\mathrm{MgO})_{\text {free }} \\
\end{array}$ & $\mathrm{Cr}$ \\
\hline $\begin{array}{c}\text { Solid residue of sodium } \\
\text { carbonate production } \\
\text { (SRS) }\end{array}$ & $5-12$ & $40-50$ & $1.8-2.6$ & $0.2-1.0$ & $2.8-4.7$ & $1-3$ & $1-5$ & $5-12$ & $3-12$ \\
\hline $\begin{array}{l}\text { Waste of slaking the lime } \\
\text { (WSL) }\end{array}$ & $2-4.5$ & $58-62$ & $1.0-2.5$ & $0.15-0.25$ & 2.0 & $1.3-4.0$ & $2-3$ & $22-35$ & $0.3-0.5$ \\
\hline Cement kiln dust (CKD) & $13-15$ & $42-45$ & $2-3$ & $1.0-1.5$ & $3-6$ & $2.5-4.0$ & 0.7 & $6-7$ & $0.3-0.5$ \\
\hline
\end{tabular}

Table 3. Chemical composition of phosphogypsum of JSC "Meleuzovskie mineral fertilizers", \%.

\begin{tabular}{cccccc}
\hline $\mathbf{C a O}$ & $\mathbf{S O}_{3}$ & $\mathbf{H}_{\mathbf{2}} \mathbf{C}$ & $\mathbf{P}_{\mathbf{2}} \mathbf{O}_{\mathbf{5}}$ & $\mathbf{R}_{\mathbf{2}} \mathbf{O}_{\mathbf{3}}$ & $\mathbf{R}_{\mathbf{2}} \mathbf{O}$ \\
\hline 31.5 & 46.76 & 18.9 & 0.89 & 0.24 & 0.42 \\
\hline
\end{tabular}

The concrete water resistance was determined according to EN 12390.8.2009_ “Testing hardened concrete-Part 8: Depth of penetration of water under pressure". The concrete 
frost resistance was determined according to EN 12390.9—“"Testing hardened concretePart 9: Freeze-thaw resistance with de-icing salts-Scaling".

The following studies were performed to obtain the data on changes in the strength properties of concrete during operation in livestock complexes. Samples-prisms of a $25 \times 25 \times 100 \mathrm{~mm}^{3}$ size were made with the ratio of binder-to-sand equal to 1:3, and with fine aggregate fraction $<2.5 \mathrm{~mm}$. Samples were placed into tap water and the aggressive media of a livestock farm after the 28-day curing period under normal conditions.

The chemical composition of the aggressive media formed during the life of the animals depends on the type and number of animals, as well as on the method of their maintenance and the system of manure removal. The liquid media in this study was composed of $95.7 \%$ water and $4.3 \%$ dry substance: $2 \%$ urea, $0.05 \%$ uric acid, $0.35 \%$ sodium ion, $0.15 \%$ potassium ion, $0.04 \%$ magnesium ion, $0.06 \%$ calcium ion, $0.27 \%$ chloride ion, and $0.78 \%$ sulfate ion. The microflora saturation was $8 \times 10^{7}$ bacteria per $1 \mathrm{~cm}^{3}$.

The resistance of samples to the aggressive media of the livestock farm was determined by the resistance coefficient $K_{r}$ as the ratio of the value of the average limit of bending strength after 105 and 150 days of storage in the aggressive media to the value of the average limit of bending strength after storage in tap water.

\section{Approaches to Assessing the Impact of Clinker-Free Cements on the Environment}

Concrete durability based on clinker-free cements in the required operating conditions is an important criterion, along with the involvement of wastes and by-products of the industry of cement production. For example, clinker-free cements can be produced from waste materials with a very low CF but the concrete based on it will have a short service life in comparison with the concrete based on OPC. On the other hand, OPC-based concrete can have a very short service life under certain operating conditions compared with clinker-free cement. It should also be taken into account that some components, such as hardening activators or superplasticizers, can be produced by using a technology with a considerable $\mathrm{CF}$.

The authors [48] found that the $\mathrm{CF}$ from the production processes of alkaline activators (hydroxides and alkaline silicates) varied from $0.9 \mathrm{t} / \mathrm{t}$ to $1.8 \mathrm{t} / \mathrm{t}$ (dry base). The production of these synthetic products is associated with industrial processes with a considerable CF. However, these activators are added into clinker-free cements in small amounts (a small percent of the binder mass), so their total contribution to the $\mathrm{CF}$ of clinker-free cement production cannot exceed $0.05 \mathrm{t}$ of $\mathrm{eCO}_{2}$ per cement ton [48]). This is much lower than the $\mathrm{CF}$ of producing one ton of OPC. Clinker-free cements may contain natural alkaline salts or industrial by-products as hardening activators. In this case, the $\mathrm{CF}$ from producing one ton of clinker-free cement is reduced.

The CF of a product is calculated per ton of cement or a cubic meter of concrete in the majority of the published studies [48-50,55]. However, as it was noted above, it is necessary to take into account the concrete properties that determine its durability in specific operating conditions, that is, the field of concrete application. Accordingly, it is advisable to compare the CF of concretes based on OPC and clinker-free cement taking the main concrete property (or properties) under these operating conditions (namely, the measurement unit of this property) as a functional unit. For example, compressive strength, impact strength, and frost resistance of concrete are equally important characteristics for the concrete of railway sleepers, in accordance with the requirements of regulatory documentation in transport construction. Compressive strength, flexural tensile strength, and resistance to corrosion are equally important characteristics for the concrete of livestock farm flooring. Thus, all normative characteristics, depending on the purpose and operating conditions of the concrete, must be taken into account when assigning a functional unit.

The $\mathrm{CF}$ reflects the sum of emissions and removals of greenhouse gases, expressed as the $\mathrm{eCO}_{2}$, by products that are associated with the stages of obtaining raw materials, production, use, and disposal of wastes from the products at the final stages of their life cycles. When comparing concretes based on OPC and clinker-free cement, it should be noted that there may be significant differences in the amount of $\mathrm{eCO}_{2}$ at the stage 
of obtaining raw materials for concrete (namely, obtaining a binder) and at the stage of its use (namely, the duration of concrete operation). The other stages, such as fresh concrete production and concrete wastes re-use, can have almost a similar partial CF for both concretes based on OPC and clinker-free cement, within the framework of the same construction project.

Thus, the comparison of compositions and properties of concrete is advisable to perform for the comparative assessment of CF of various kinds of cements. It is necessary to distinguish such terms as the carbon footprint of cement production (process) and the carbon footprint of cement (product). The second term should be used to assess the CF of cement in concrete composition.

\section{Selecting the Functional Unit for Assessing the Environmental Impact of Clinker-Free Cement}

A common functional unit is required to compare two products, such as OPC-based concrete and clinker-free cement-based concrete. Most researchers focus on comparing the CF of component production only for the cement matrix of both concretes, since both kinds of equal-strength concretes have the same type of aggregates within the same construction site. The cement mass required to provide the equal compressive strength at the age of 28 days for concrete based on OPC and on clinker-free cement is taken as a functional unit. The choice of a functional unit has an essential impact on the results of a quantitative assessment of the CF [56-58].

Analysis of the $\mathrm{eCO}_{2}$ normalized for compressive strength at the age of 28 days, depending on the mixture compositions based on Portland cements CEM I 32.5 and CEM I 52.5, has shown that the optimum concrete strength exists (usually about $60 \mathrm{MPa}$ ) when the value of $\mathrm{eCO}_{2}$ per $1 \mathrm{MPa}$ of strength is minimal [58]. It is necessary to increase the Portland cement amount as well as to use a superplasticizer for increasing the concrete strength. This leads to a considerable increase of $\mathrm{eCO}_{2}$ per $1 \mathrm{MPa}$ of concrete strength. Hence, it is necessary to look for technological ways to increase the concrete strength without increasing $\mathrm{eCO}_{2}$ per $1 \mathrm{MPa}$, for example, the method of using microsilica.

The authors [51] have considered the environmental impact of concrete compressive strength by introducing a bi criterion that is the ratio of cement mass per cubic meter of concrete to 28-day compressive strength. However, in this case, only one functional property of cement (compressive strength of concrete at the age of 28 days) was considered.

The study [59] is directed to the introduction of a new functional unit (FU) for the assessment of the CF at the concrete mix production stage. For this purpose, the new FU includes the functional properties of cement, namely the compressive strength and service life of the concrete. In this case, the FU is defined as the binder mass $(\mathrm{kg})$ per $1 \mathrm{MPa}$ of strength and 1 year of concrete service life $\left(\mathrm{kg} \cdot \mathrm{MPa}^{-1} \cdot \mathrm{year}^{-1}\right)$. According to this approach, the cements with a low environmental impact are those that lead to producing the concrete with the highest compressive strength and service life at the lowest cement amounts.

It should be noted that in the case of developing new compositions of clinker-free cements, it is difficult to determine their service life because of the lack of data on their operation in construction. It is possible to obtain the required characteristics of concrete based on clinker-free cements depending on operating conditions and to predict the concrete service life using software products. However, this will add uncertainty to the result.

The authors of the papers $[17,60,61]$ note that it is necessary to take into account the cement impact on the environment based on concrete durability. It is the values of the concrete characteristics in specific operating conditions that should be compared with the values of the same characteristics of concrete based on OPC in identical conditions.

Results supporting the importance of using service life in the CF estimation are shown in paper [62-64], where data on the chloride diffusion coefficient, the aging coefficient, and the chloride threshold for seven concrete mixtures with OPC, OPC + FA (fly ash) and limestone-calcined clay cement (LC3) are presented. The service life was then modeled using this data. It was found that the service life of a typical bridge pier and beam based on FA and LC3 concrete was much higher than that of OPC-based concrete of the same 
strength. Based on the results of LCA, it was found that the CF of concrete with FA and LC3 was much lower than the CF of concrete based on OPC of similar strength.

Thus, it is necessary to justify the choice of a FU for comparative analysis of the CF from cement production and the $\mathrm{CF}$ of using the multicomponent cements in concrete since the assessment of CF per $1 \mathrm{~kg}$ of cement and $1 \mathrm{MPa}$ of strength is insufficient for making strategic or design decisions.

The authors of this paper suggest the following methodological approach for the selection of an FU for comparative assessment of the CF of concrete products (presented in Figure 1).
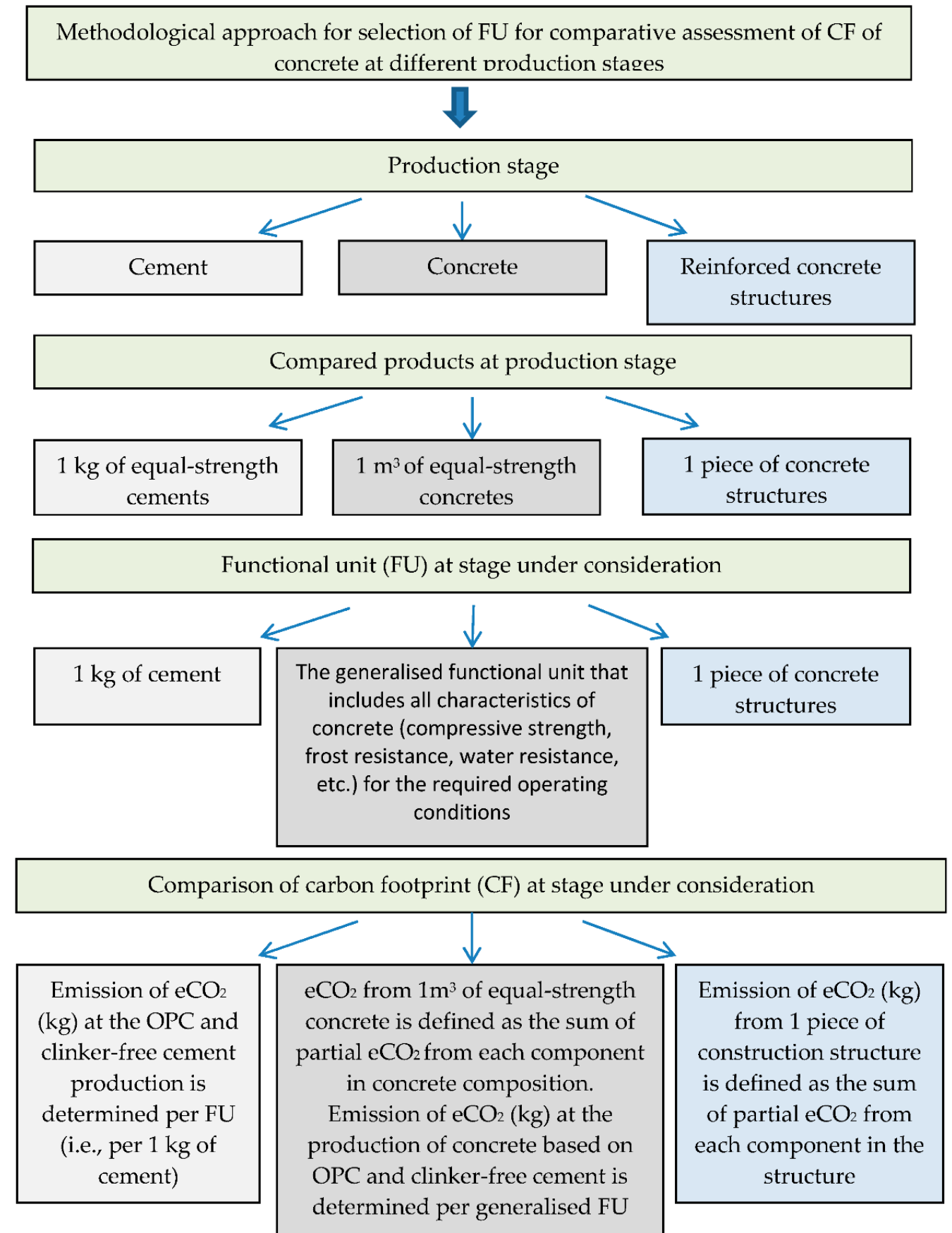

Figure 1. Methodological approach for selection of functional unit (FU) for comparative assessment of the carbon footprint (CF) of concrete products. 
Three general approaches to reducing the cement impact on the environment by decreasing the carbon footprint should be highlighted. The first approach is used at the stage of cement production by replacing clinker with mineral components, and by using alternative fuels, and so forth. The second approach is used at the stage of fresh concrete production by reducing the cement amount and by optimizing the transportation of components for mixing, and so forth. The third approach is used at the stage of production of reinforced concrete structures by reducing the structure size while increasing the strength characteristics of concrete, replacing steel fiber with synthetic ones, and so forth.

The compositions and characteristics of concretes based on OPC, slag Portland cement, and alkali-activated slag binders are shown in Table 4. The studied concretes are used in transport construction. The requirements for frost resistance, along with compressive strength, are imposed for railway sleepers and, additionally, the water resistance for road slabs.

Table 4. Compositions and properties of concretes based on various binders.

\begin{tabular}{|c|c|c|c|c|}
\hline No. & Binder & $\begin{array}{l}\text { Compressive } \\
\text { Strength, } \mathrm{MPa}\end{array}$ & $\begin{array}{c}\text { Frost Resistance, } \\
\text { Cycles }\end{array}$ & $\begin{array}{c}\text { Water Resistance, } \\
\text { MPa }\end{array}$ \\
\hline 1 & CEM 32.5 & 40 & 300 & 1.5 \\
\hline 2 & CEM 52.5 & 60 & 600 & 2.1 \\
\hline 3 & $\begin{array}{l}\text { Slag Portland } \\
\text { cement CEM } \\
\text { III32.5 }\end{array}$ & 37 & 300 & 2.0 \\
\hline 4 & $\begin{array}{l}\text { Slag Portland } \\
\text { cement } \\
\text { CEM III } 42.5\end{array}$ & 41 & 400 & 2.0 \\
\hline \multicolumn{5}{|c|}{ Slag No.1 $\left(\mathrm{M}_{\mathrm{O}}=0.8\right)$} \\
\hline 5 & Only slag & 2 & 25 & 0.5 \\
\hline 6 & Slag $+\mathrm{Na}_{2} \mathrm{CO}_{3} *$ & 40 & 300 & 1.5 \\
\hline 7 & Slag $+\mathrm{NaOH}^{*}$ & 35 & 150 & 1.5 \\
\hline 8 & Slag $+\mathrm{Na}_{2} \mathrm{SiO}_{3}$ * & 70 & 600 & 2.2 \\
\hline 9 & Slag $+\mathrm{K}_{2} \mathrm{CO}_{3} *$ & 40 & 180 & 1.7 \\
\hline \multicolumn{5}{|c|}{ Slag No.2 $\left(\mathrm{M}_{\mathrm{o}}=0.9\right)$} \\
\hline 10 & Only slag & 3 & 30 & 0.3 \\
\hline 11 & Slag $+\mathrm{Na}_{2} \mathrm{CO}_{3} *$ & 50 & 400 & 2.0 \\
\hline 12 & $\mathrm{Slag}+\mathrm{NaOH}^{*}$ & 40 & 200 & 1.0 \\
\hline 13 & Slag $+\mathrm{Na}_{2} \mathrm{SiO}_{3}$ * & 78 & 700 & 2.5 \\
\hline
\end{tabular}

$\mathrm{M}_{\mathrm{o}}$-slag basicity modulus. *-an alkaline additive taken in the amount of $5 \%$ of slag mass.

Concretes based on alkali-activated slag (Compositions 8 and 13) meet the requirements for the concrete of railway sleepers because the compressive strength and the frost resistance were $70 \mathrm{MPa}$ and $\mathrm{F} 600$, respectively, by using the granulated blast furnace slag with a basicity modulus of 0.8 , and $78 \mathrm{MPa}$ and F700, respectively, by using the granulated blast furnace slag with a basicity modulus of 0.9 . These concretes have almost similar characteristics with concrete based on CEM 52.5 (Composition 2), for which the values were $60 \mathrm{MPa}$ and F600. Besides that, the alkali-activated slag concretes had increased impact strength [65].

Compositions 4, 6, and 11 meet the requirements for road concretes (namely a B30 or B35 compressive strength class and frost resistance of not less than F300) and have almost similar characteristics with Composition 1 on Portland cement (Table 5). Using the approach from Table 4 and choosing the concrete grade of frost resistance (or both indicators such as frost resistance and water resistance) for equal-strength concretes as a 
functional unit, it may be concluded that clinker-free cements can have a CF lower than that of OPC.

Table 5. Compositions of supersulfated slag binders.

\begin{tabular}{|c|c|c|c|c|c|c|c|c|}
\hline \multirow[b]{3}{*}{ No. } & \multicolumn{8}{|c|}{ Binder Composition } \\
\hline & \multicolumn{3}{|c|}{ Slag } & \multicolumn{3}{|c|}{ Sulfate Component } & \multicolumn{2}{|c|}{ Activator } \\
\hline & Type & $\begin{array}{c}\text { Specific } \\
\text { Surface Area, } \\
\mathrm{cm}^{2} / \mathrm{g}\end{array}$ & Mass, $\%$ & Type & $\begin{array}{c}\text { Specific } \\
\text { Surface Area, } \\
\mathrm{cm}^{2} / \mathrm{g}\end{array}$ & Mass, $\%$ & Type & Mass, $\%$ \\
\hline 6.1 & No.2 & 3200 & 80 & FG & 6000 & 20 & SKD & 10 \\
\hline 6.2 & No. 2 & 3200 & 80 & FG & 6000 & 20 & WSL & 5 \\
\hline 6.3 & No. 2 & 3200 & 80 & FG & 6000 & 20 & SRS & 10 \\
\hline 6.4 & \multicolumn{8}{|c|}{ CEM I32.5 } \\
\hline 6.5 & \multicolumn{8}{|c|}{ CEM III22.5 } \\
\hline
\end{tabular}

FG-phosphogypsum; the abbreviations of SKD, WSL and SRS-see in Table 2.

Local natural aggregates are used for producing the concrete for railway sleepers. The choice of aggregates for the concrete based on OPC should be carried out, taking into account the exclusion of the alkali-silica corrosion of concrete. However, the availability of such natural aggregates is limited in many regions. This fact indicates the necessity of using cements with alkaline activation. Alkali-silica corrosion, namely, the formation of substances of greater volume as a result of reactions, leads to the concrete cracking. It is less intense in alkali-activated cements than in OPC since all the alkalis are consumed for the activation of aluminosilicates in slag. Advantages of alkali-activated cements over OPC, such as high frost resistance, impact strength, and resistance to alkali-silica expansion on local aggregates, have been confirmed by the experience of using the reinforced concrete sub-rail structures based on the alkali-activated slag concrete for several decades [36].

The second example is that the use of supersulfated slag binder for floorings in livestock complexes shows that the service life of floorings in the aggressive environment considerably increases in comparison with the service life of floorings built from concrete based on OPC [37]. The compositions and properties of concrete based on supersulfated slag binders are presented in Tables 5 and 6 .

Table 6. Cement and concrete properties.

\begin{tabular}{|c|c|c|c|c|c|c|}
\hline \multirow{2}{*}{ No. } & \multicolumn{2}{|c|}{ Setting Time of Cement Paste, h-min } & \multirow{2}{*}{ Water/Binder } & \multicolumn{2}{|c|}{ Strength at 28 Days, $\mathrm{MPa}$} & \multirow{2}{*}{$\begin{array}{c}\text { Frost } \\
\text { Resistance, } \\
\text { Cycles }\end{array}$} \\
\hline & Begin & End & & $\begin{array}{l}\text { Tensile Strength } \\
\text { in Bending }\end{array}$ & $\begin{array}{l}\text { Compressive } \\
\text { Strength }\end{array}$ & \\
\hline 6.1 & $2-40$ & $7-00$ & 0.48 & 5.1 & 36.2 & 70 \\
\hline 6.2 & $2-20$ & $6-10$ & 0.47 & 4.8 & 35.0 & 65 \\
\hline 6.3 & $3-30$ & $9-10$ & 0.47 & 4.4 & 28.0 & 60 \\
\hline 6.4 & $2-20$ & $5-20$ & 0.38 & 5.6 & 42,0 & 150 \\
\hline 6.5 & $2-40$ & $6-10$ & 0.41 & 4.6 & 31.7 & 110 \\
\hline
\end{tabular}

The resistance of samples to the aggressive media of the livestock farm was determined by the resistance coefficient $\mathrm{K}_{\mathrm{r}}$ after 105 and 150 days of storage in the aggressive media (Table 7). The aggressive environment significantly worsened the strength indicators of concrete based on OPC. 
Table 7. Changes of bending strength.

\begin{tabular}{|c|c|c|c|c|c|c|}
\hline \multirow{3}{*}{ No. } & \multicolumn{6}{|c|}{ Tensile Strength in Bending (MPa) after Storage: } \\
\hline & \multicolumn{3}{|c|}{105 Days } & \multicolumn{3}{|c|}{150 days } \\
\hline & In Tap Water & $\begin{array}{c}\text { In Aggressive } \\
\text { Media }\end{array}$ & $\begin{array}{c}\text { Resistance } \\
\text { Coefficient } K_{\mathrm{r}}\end{array}$ & In Tap Water & $\begin{array}{c}\text { In Aggressive } \\
\text { Media }\end{array}$ & $\begin{array}{l}\text { RESISTANCE } \\
\text { Coefficient } K_{r}\end{array}$ \\
\hline 6.1 & 7.2 & 6.8 & 0.94 & 8.4 & 7.5 & 0.90 \\
\hline 6.2 & 6.8 & 6.1 & 0.90 & 7.7 & 6.7 & 0.87 \\
\hline 6.3 & 6.1 & 5.1 & 0.83 & 7.0 & 5.6 & 0.80 \\
\hline 6.4 & 8.8 & 5.8 & 0.66 & 9.7 & 5.1 & 0.53 \\
\hline 6.5 & 6.9 & 5.4 & 0.78 & 7.6 & 5.7 & 0.75 \\
\hline
\end{tabular}

One can see in Table 7 that the concrete based on OPC has the least resistance to the aggressive media since the bending strength was reduced almost twice after 150 days. CEM III 22.5 and supersulfated slag binder had better values of the resistance coefficient. The binder of Composition 6.1, which contains $10 \%$ of cement dust as an alkaline activator, had the highest resistance with $K_{r}=0.90$. It should be noted that the destruction process and reduction of strength characteristics of samples based on OPC progress until their complete destruction. Conversely, the strength characteristics stabilized over time in samples with supersulfated slag binder, which shows the attenuating nature of the corrosion process. This is an example in which the exclusion of clinker can improve the physical and mechanical properties of concrete and increase its service life in specific operating conditions.

Thus, the selection of a functional unit for a quantitative assessment of the carbon footprint of concrete should be performed, taking into account the concrete properties for the required operating conditions.

\section{Conclusions}

The need to consider all the properties of concrete that determine its durability in order to assess the environmental impact of clinker-free cements is discussed in this paper. The selection of a functional unit for quantifying the carbon footprint of Portland cement and clinker-free cement, in order to compare their environmental impact, must be carried out, taking into account all the properties of concrete for the required operating conditions. The high strength of concrete is not the only condition for ensuring its durability. Accordingly, it is not sufficient to consider only strength as a functional unit. It is necessary to take into account other properties that determine the durability of the material under the required operating conditions.

Concretes based on clinker-free binders that confirmed the required durability by operating in real construction projects, namely as flooring structures of livestock complexes and prestressed reinforced concrete sub-rail structures on the railway, were considered to justify the choice of a functional unit.

The results of laboratory tests show that concrete based on OPC had the least resistance since the bending strength was reduced twice after 150 days of storage in the aggressive media. CEM III 22.5 and supersulfated slag binder had better values of the resistance coefficient. The highest resistance with $\mathrm{K}=0.90$ was seen in the supersulfated slag binder of the following composition: ground granulated blast furnace slag of $80 \%$, phosphogypsum of $20 \%$, and cement kiln dust as an alkaline activator in a quantity of $10 \%$ from the mass of slag and phosphogypsum. It should be noted that the destructing process and reduction of strength characteristics of samples based on OPC progress until their complete destruction. Conversely, the strength characteristics stabilized over time in samples based on supersulfated slag binders, which indicates the attenuating nature of the corrosion process. This is an example in which the exclusion of clinker can improve the physical and mechanical properties of concrete and increase its service life in specific operating conditions. Thus, all four characteristics of concrete durability (compressive strength, 
flexural tensile strength, frost resistance, and corrosion resistance) should be taken into account as part of the functional unit that will lead to a decrease in the carbon footprint of concrete of clinker-free cement, which is used in flooring structures of livestock complexes.

Concrete based on alkali-activated slag had the compressive strength 70MPa, frost resistance of $\mathrm{F} 600$, and water resistance of $2.2 \mathrm{MPa}$, using the granulated blast furnace slag with a basicity modulus of 0.8 , and 78MPa, F700, and $2.5 \mathrm{MPa}$, respectively, using the granulated blast furnace slag with a basicity modulus of 0.9 . These concretes had comparable characteristics with concrete based on CEM 52.5, for which the values were $60 \mathrm{MPa}, \mathrm{F} 600$ and $2.1 \mathrm{MPa}$, respectively. These results also indicate that as a functional unit for comparative quantification of the carbon footprint of cements, it is necessary to take into account the generalized functional unit, which includes three characteristics of concrete (compressive strength, frost resistance, and water resistance) for the studied case of concrete application.

Author Contributions: Conceptualization, O.S. and L.K.; methodology, L.K. and J.K.; validation, O.S. and X.G.; formal analysis, L.K., H.T., X.G.; investigation, L.K. and O.S.; resources O.S.; writingoriginal draft preparation, L.K. and O.S.; writing-review and editing, J.K. and H.T.; supervision O.S.; All authors have read and agreed to the published version of the manuscript.

Funding: This research received no external funding.

Data Availability Statement: Data is contained within the article or supplementary material.

Conflicts of Interest: The authors declare no conflict of interest.

\section{References}

1. Karapetian, K.; Dzhevaga, N. Modern technologies of complex processing of phosphates. ARPN J. Eng. Appl. Sci. 2017, 12, 4588-4594.

2. Gorlanov, E.S.; Bazhin, V.Y.; Vlasov, A.A. Electrochemical borating of titanium-containing carbographite materials. Russ. Metall. 2017, 2017, 489-493. [CrossRef]

3. Brichkin, V.N.; Kurtenkov, R.V.; Eldeeb, A.B.; Bormotov, I.S. State and development options for the raw material base of aluminum in non-bauxite regions. Obogashchenie Rud 2019, 4, 36-41. [CrossRef]

4. Chen, L.; Wang, L.; Tsang, D.C.; Mechtcherine, V.; Poon, C.S. Efficacy of green alternatives and carbon dioxide curing in reactive magnesia cement-bonded particleboards. J. Clean. Prod. 2020, 258, 120997. [CrossRef]

5. Beloglazov, I.I.; Bazhin, V.Y.; Zyryanova, O.V. Upgrading of the process of technological pulp separation in modern pressure filters. Non-Ferr. Met. 2016, 1, 38-40. [CrossRef]

6. Litvinenko, V.S. Digital Economy as a Factor in the Technological Development of the Mineral Sector. Nat. Resour. Res. 2020, 29, 1521-1541. [CrossRef]

7. Litvinenko, V.S.; Sergeev, I.B. Innovations as a Factor in the Development of the Natural Resources Sector. Stud. Russ. Econ. Dev. 2019, 30, 637-645. [CrossRef]

8. Tcvetkov, P.; Cherepovitsyn, A.; Fedoseev, S. The changing role of CO2 in the transition to a circular economy: Review of carbon sequestration projects. Sustainability 2019, 11, 5834. [CrossRef]

9. Pashkevich, M.A.; Bech, J.; Matveeva, V.A.; Alekseenko, A.V. Biogeochemical assessment of soils and plants in industrial, residential and recreational areas of Saint Petersburg. J. Min. Inst. 2020, 241, 125-130. [CrossRef]

10. ElDeeb, A.B.; Brichkin, V.N.; Kurtenkov, R.V.; Bormotov, I.S. Extraction of alumina from kaolin by a combination of pyro-and hydro-metallurgical processes. Appl. Clay Sci. 2019, 172, 146-154. [CrossRef]

11. Scrivener, K.L.; John, V.M.; Gartner, E.M. Eco-efficient cements: Potential economically viable solutions for a low-CO2 cementbased materials industry. Cem. Concr. Res. 2018, 114, 2-26. [CrossRef]

12. Gartner, E.; Sui, T. Alternative cement clinkers. Cem. Concr. Res. 2018, 114, 27-39. [CrossRef]

13. Juenger, M.C.G.; Snellings, R.; Bernal, S.A. Supplementary cementitious materials: New sources, characterization, and performance insights. Cem. Concr. Res. 2019, 122, 257-273. [CrossRef]

14. Shi, C.; Qu, B.; Provis, J.L. Recent progress in low-carbon binders. Cem. Concr. Res. 2019, 122, 227-250. [CrossRef]

15. Trindade, A.C.C.; Heravi, A.A.; Curosu, I.; Liebscher, M.; de Andrade Silva, F.; Mechtcherine, V. Tensile behavior of strainhardening geopolymer composites (SHGC) under impact loading. Cem. Concr. Compos. 2020, 113, 103703. [CrossRef]

16. Alekseev, A.V. Face deformation in tunneling in the zone of structural and mechanical heterogeneity. Min. Inf. Anal. Bull. 2018, 12, 48-56. [CrossRef]

17. Palomo, A.; Monteiro, P.; Martauz, P.; Bílek, V.; Fernandez-Jimenez, A. Clinker-free binders: A journey from the past to a sustainable future (opus caementicium futurum). Cem. Concr. Res. 2019, 124, 105829. [CrossRef]

18. García-Lodeiro, I.; Fernández-Jiménez, A.; Palomo, A. Variation in clinker-free cements over time. Alkaline activation of fly ash-portland cement blends. Cem. Concr. Res. 2013, 52, 112-122. [CrossRef] 
19. Fernández-Jiménez, A.; Garcia-Lodeiro, I.; Maltseva, O.; Palomo, A. Hydration mechanisms of clinker-free cements as a function of the way of addition of chemicals. J. Am. Ceram. Soc. 2019, 102, 427-436. [CrossRef]

20. Al Makhadmeh, W.A.; Soliman, A. Effect of activator nature on property development of alkali-activated slag binders. J. Sustain. Cem. Based Mater. 2020, 1-17. [CrossRef]

21. Klyuev, S.V.; Klyuev, A.V.; Vatin, N.I. Fiber concrete for the construction industry. Mag. Civ. Eng. 2018, 84, 41-47. [CrossRef]

22. Namsone, E.; Korjakins, A.; Sahmenko, G.; Sinka, M. The environmental impacts of foamed concrete production and exploitation. IOP Conf. Ser. Mater. Sci. Eng. 2017, 251, 012029. [CrossRef]

23. Sprince, A.; Pakrastins, L.; Gailitis, R. Long-Term Parameters of New Cement Composites. In 3rd International Conference on the Application of Superabsorbent Polymers (SAP) and Other New Admixtures towards Smart Concrete. SAP 2019; Boshoff, W., Combrinck, R., Mechtcherine, V., Wyrzykowski, M., Eds.; RILEM Bookseries; Springer: Cham, Switzerland, 2020; Volume 24, pp. 85-94.

24. Erofeev, V.T.; Rodin, A.I.; Yakunin, V.V.; Tuvin, M.N. Structure, composition and properties of geopolymers from mineral wool waste. Mag. Civ. Eng. 2019, 90, 3-14. [CrossRef]

25. Taskin, A.; Fediuk, R.; Grebenyuk, I.; Elkin, O.; Kholodov, A. Effective cement binders on fly and slag waste from heat power industry of the primorsky krai, Russian federation. Int. J. Sci. Technol. Res. 2020, 9, 3509-3512.

26. Krivenko, P. Why alkaline activation-60 years of the theory and practice of alkali-activated materials. J. Ceram. Sci. Technol. 2017, 8, 323-333.

27. Krivenko, P.V.; Petropavlovskyi, O.; Kovalchuk, O.; Cao, H.L.; Weng, L.Q. Efficiency of the Alkali-Activated Cement Concretes for Sea Construction. Mater. Sci. Forum 2019, 968, 3-12. [CrossRef]

28. Qu, B.; Martin, A.; Pastor, J.Y.; Palomo, A.; Fernández-Jiménez, A. Characterisation of pre-industrial clinker-free cement and effect of pre-curing temperature. Cem. Concr. Compos. 2016, 73, 281-288. [CrossRef]

29. Martauz, P.; Janotka, I.; Strigáč, J.; Bačuvčík, M. Fundamental properties of industrial clinker-free cement: Utilization in ready-mixed concretes and shrinkage-reducing applications. Mater. Constr. 2016, 66, 084.

30. Luukkonen, T.; Abdollahnejad, Z.; Ohenoja, K.; Kinnunen, P.; Illikainen, M. Suitability of commercial superplasticizers for one-part alkali-activated blast-furnace slag mortar. J. Sustain. Cem. Based Mater. 2019, 8, 244-257. [CrossRef]

31. Bazhenov, Y.; Kozlova, I.; Nechaev, K.; Kryuchkova, A. The use of finely ground slag in portland cement with mineral additives. In E3S Web of Conferences; EDP Sciences: Les Ulis, France, 2019; Volume 91, p. 02044.

32. Yazdi, M.A.; Liebscher, M.; Hempel, S.; Yang, J.; Mechtcherine, V. Correlation of microstructural and mechanical properties of geopolymers produced from fly ash and slag at room temperature. Constr. Build. Mater. 2018, 191, 330-341. [CrossRef]

33. Zhang, J.; He, X.; Yang, W.; Deng, X. Utilization of carbide slag-granulated blast furnace slag system by wet grinding as low carbon cementitious materials. Constr. Build. Mater. 2020, 249, 118763. [CrossRef]

34. Bisikirske, D.; Blumberga, D.; Vasarevicius, S.; Skripkiunas, G. Multicriteria Analysis of Glass Waste Application. Environ. Clim. Technol. 2019, 23, 152-167. [CrossRef]

35. Grengg, C.; Ukrainczyk, N.; Koraimann, G.; Mueller, B.; Dietzel, M.; Mittermayr, F. Long-term in situ performance of geopolymer, calcium aluminate and Portland cement-based materials exposed to microbially induced acid corrosion. Cem. Concr. Res. 2020, 131, 106034. [CrossRef]

36. Petrova, T.M. Concrete for Transport Construction Based on Cement-Free Binders. Ph.D. Thesis, Petersburg State Transport University, Saint Petersburg, Russia, 1997; p. 511.

37. Kazanskaya, L.F. Supersulphated Slag Binders and Concretes Based on Them (Based on Waste from the Chemical Industry of the South Ural Region). Ph.D. Thesis, Petersburg State Transport University, Saint Petersburg, Russia, 2000; p. 326.

38. Kazanskaya, L.F.; Smirnova, O.M. Technological approaches to increase the quality of lightweight concrete based on clinker-free binders. In IOP Conference Series: Materials Science and Engineering; IOP Publishing: Bristol, UK, 2019; Volume 666, p. 012038.

39. Gartner, E.; Hirao, H. A review of alternative approaches to the reduction of $\mathrm{CO} 2$ emissions associated with the manufacture of binder phase in concrete. Cem. Concr. Res. 2015, 78, 126-142. [CrossRef]

40. Lothenbach, B.; Scrivener, K.; Hooton, R.D. Supplementary cementitious materials. Cem. Concr. Res. 2011, 41, 1244-1256. [CrossRef]

41. Sinka, M.; Van den Heede, P.; De Belie, N.; Bajare, D.; Sahmenko, G.; Korjakins, A. Comparative life cycle assessment of magnesium binders as an alternative for hemp concrete. Resources. Conserv. Recycl. 2018, 133, 288-299. [CrossRef]

42. Rakhimova, N.R.; Rakhimov, R.Z. Literature review of advances in materials used in development of alkali-activated mortars, concretes, and composites. J. Mater. Civ. Eng. 2019, 31, 03119002. [CrossRef]

43. Donatello, S.; Maltseva, O.; Fernandez-Jimenez, A.; Palomo, A. The early age hydration reactions of clinker-free cement containing a very high content of coal bottom ash. J. Am. Ceram. Soc. 2014, 97, 929-937. [CrossRef]

44. El-Hassan, H.; Ismail, N. Effect of process parameters on the performance of fly ash/GGBS blended geopolymer composites. J. Sustain. Cem. Based Mater. 2018, 7, 122-140. [CrossRef]

45. Krivenko, P.; Gelevera, O.; Kovalchuk, O.; Bumanis, G.; Korjakins, A. Alkali-aggregate reaction in alkali-activated cement concretes. In IOP Conference Series: Materials Science and Engineering; IOP Publishing: Bristol, UK, 2019; Volume 660, p. 012002.

46. Ochkurov, V.I.; Vilenskii, M.Y. Comparative evaluation of the saving of binder with fine ground slag. In IOP Conference Series: Materials Science and Engineering; IOP Publishing: Bristol, UK, 2019; Volume 666, p. 012026.

47. Kalina, L.; Bílek, V.; Kiripolský, T.; Novotný, R.; Másilko, J. Cement Kiln By-Pass Dust: An Effective Alkaline Activator for Pozzolanic Materials. Materials 2018, 11, 1770. [CrossRef] 
48. Habert, G.; Ouellet-Plamondon, C. Recent update on the environmental impact of geopolymers. Rilem Tech. Lett. 2016, 1, 17-23. [CrossRef]

49. Teh, S.H.; Wiedmann, T.; Castel, A.; de Burgh, J. Clinker-free life cycle assessment of greenhouse gas emissions from cement, concrete and geopolymer concrete in Australia. J. Clean. Prod. 2017, 152, 312-320. [CrossRef]

50. Li, C.; Cui, S.; Nie, Z.; Gong, X.; Wang, Z.; Itsubo, N. The LCA of Portland cement production in China. Int. J. Life Cycle Assess. 2015, 20, 117-127. [CrossRef]

51. Damineli, B.L.; Kemeid, F.M.; Aguiar, P.S.; John, V.M. Measuring the eco-efficiency of cement use. Cem. Concr. Compos. 2010, 32, 555-562. [CrossRef]

52. Gursel, A.P.; Masanet, E.; Horvath, A.; Stadel, A. Life-cycle inventory analysis of concrete production: A critical review. Cem. Concr. Compos. 2014, 51, 38-48. [CrossRef]

53. Zimele, Z.; Sinka, M.; Korjakins, A.; Bajare, D.; Sahmenko, G. Life Cycle Assessment of Foam Concrete Production in Latvia. Environ. Clim. Technol. 2019, 23, 70-84. [CrossRef]

54. Mohammadi, J.; South, W. Life cycle assessment (LCA) of benchmark concrete products in Australia. Int. J. Life Cycle Assess. 2017, 22, 1588-1608. [CrossRef]

55. Salas, D.A.; Ramirez, A.D.; Ulloa, N.; Baykara, H.; Boero, A.J. Life cycle assessment of geopolymer concrete. Constr. Build. Mater. 2018, 190, 170-177. [CrossRef]

56. Panesar, D.; Seto, K.; Churchill, C. Impact of the selection of functional unit on the life cycle assessment of green concrete. Int. J. Life Cycle Assess. 2017, 22, 1969-1986. [CrossRef]

57. Robayo-Salazar, R.; Mejía-Arcila, J.; de Gutiérrez, R.M.; Martínez, E. Life cycle assessment (LCA) of an alkali-activated binary concrete based on natural volcanic pozzolan: A comparative analysis to OPC concrete. Constr. Build. Mater. 2018, 176, 103-111. [CrossRef]

58. Purnell, P.; Black, L. Embodied carbon dioxide in concrete: Variation with common mix design parameters. Cem. Concr. Res. 2012, 42, 874-877. [CrossRef]

59. Gutiérrez, A.S.; Eras, J.J.C.; Gaviria, C.A.; Van Caneghem, J.; Vandecasteele, C. Improved selection of the functional unit in environmental impact assessment of cement. J. Clean. Prod. 2017, 168, 463-473. [CrossRef]

60. Messina, F.; Ferone, C.; Colangelo, F.; Roviello, G.C. Alkali activated waste fly ash as sustainable composite: Influence of curing and pozzolanic admixtures on the early-age physico-mechanical properties and residual strength after exposure at elevated temperature. Compos. Part B Eng. 2018, 132, 161-169. [CrossRef]

61. Hassan, M.; Arif, M.; Shariq, M. Use of geopolymer concrete for a cleaner and sustainable environment-a review of mechanical properties and microstructure. J. Clean. Prod. 2019, 223, 704-728. [CrossRef]

62. Pillai, R.G.; Gettu, R.; Santhanam, M.; Rengaraju, S.; Dhandapani, Y.; Rathnarajan, S.; Basavaraj, A.S. Service life and life cycle assessment of reinforced concrete systems with limestone calcined clay cement (LC3). Cem. Concr. Res. 2019, 118, 111-119. [CrossRef]

63. Barboza-Chavez, A.C.; Gómez-Zamorano, L.Y.; Acevedo-Dávila, J.L. Synthesis and Characterization of a Clinker-free Cement Based on Fly Ash, Metakaolin and Portland Cement Clinker. Materials 2020, 13, 1084. [CrossRef] [PubMed]

64. Khozin, V.; Khohryakov, O.; Baishev, D.; Makarenko, S. Low-water demand cements-a reliable way of CO2 emission reduction. In IOP Conference Series: Materials Science and Engineering; IOP Publishing: Bristol, UK, 2019; Volume 667, p. 012040.

65. Petrova, T.M.; Smirnova, O.M. Binder. Patent RU No. 2,556,563, 15 July 2014. 